\title{
Impact of Attitudinal Factors on Job Performance of Executives and Non-Executive Employees in Apparel Industry in Sri Lanka
}

\author{
K. H. H. Kottawatta
}

\begin{abstract}
On the scenario of continuous discussions on challenges faced by apparel industry in Sri Lanka, human involvement is yet to be considered as a significant organizational element. There are several human resources problems such as high labor turnover and absenteeism etc, which have made a huge barricade to minimize the effort of the achieving organizational objectives in the apparel industry. All the categories of human resources have a significant role to play in maintaining the highest labor productivity in this sector. However the available literature does not provide empirical evidence with regard to the impact of attitudinal factors on performance of executive and non-executive employees in this industry in Sri Lanka. Therefore, this study empirically investigated three attitudinal variables, which could influence on the job performance of the executive and nonexecutive employees in the apparel industry. The data were collected from a randomly selected sample of 354 executive employees and 536 non - executive employees in the apparel industry by administrating a structured questionnaire, which consisted of 85 questions/statements with 5 points scale. The data analyses included the univariate, bivariate, and multivariate analyses. The findings of the study are that job satisfaction, organizational commitment, and job involvement were positively and strongly correlated with job performance of executive employees while job satisfaction was positively and strongly correlated with job performance of non-executive employees in this sector. Organizational commitment and job involvement were positively correlated with job performance of non-executive employees in this sector. A strong and positive significant relationship exists between job satisfaction and job performance in both categories of employees. As per the multiple regression analysis, $84 \%$ of the variance in the job performance of executive employees has been accounted for by the three independent variables jointly and $83 \%$ of the variance in the job performance of non-executive employees has been accounted for by the three independent variables jointly. It is concluded that among the three attitudinal factors, especially job satisfaction should be considered to enhance the performance of executive and non-executive employees in this industry as a common attitudinal factor. However, the behaviors of attitudinal factors among executive and non-executive employees are divergent in nature.
\end{abstract}

Key words: Job Involvement, Job Performance, Job Satisfaction, Organizational Commitment 


\section{Introduction}

As a pivotal role of transferring business strategies into tactical decisions, any individual personnel or HR director, manager or officer will play any of the roles that will be dependent partly on the type and structure of the organization, its culture and the environment in which it exists (Armstrong, 1996). Therefore, unique talents among employees, including superior performance, high productivity, flexibility, innovation, and the ability to deliver high level of personal customer service are ways in which people provide a critical ingredient in developing an organization competitive position (Armstrong, 1996). Over the last two decades, as others attest, the HRM model, both among its advocated and its detractors, came to represent one of the most contentious signifiers in the managerial disclosure (Storey, 1989). Therefore, the person who works as a manager or worker in this sector is very important to keep the highest productivity and long term survival. To the best scenario of achieving organizational objectives, there should be the best human resource management practices in an organization. If there are the best human resource management practices, employees' attitudinal factors for their job performance remain as positively correlated in nature.

According to Kelegama and Epaarachi (2003), the labor cost in apparel sector in Sri Lanka was $15.5 \%$ of output in 1998 . There were few factors for low productivity of the sector, which are: poor working conditions, poor incentives for workers, high labor turnover and absenteeism, inadequate human resource development, strained employer-employee dialogue, restrictive labor regulations, low investment in technology, slow turn-around time, no garment factory standardization, and lack of professionalism in the industry (Kelegama \& Epaarachci, 2003). Among the above factors of low productivity in the garment sector, the first six factors highly contributed to poor HRM practices of the sector.

In many factories, especially those belonging to the small and medium categories, hazardous factory layouts with cramped workspace for the workers are not conducive to improving outputs. According to Kelegama and Epaarachci (2003), some factories lack basic facilities such as canteens, toilets, etc., and in many cases, regular breaks for using these facilities were not provided. The harassment, especially sexual harassment for female workers, longer working hours, no extra payment for additional hours, continuous working in both shifts, and requirements to work night shifts are the factors of poor human resources practices provided by the garment companies for their employees as per views of Kelegama and Epaarachci (2003).

In most factories, allowances are not linked to productivity and in the cases where productivity payments are made, they are in fact only flat-rate allowances rather than incentive systems (Kelegama and Epaarachci, 2003). According to the data about absenteeism and turnover, the garment sector has recorded average labor turnover rates of around $55 \%$ per annum, with the highest rate of $60 \%$ being recorded for factories in the Western province. The average absenteeism of the industry is $7.4 \%$ per month, with the highest rate of $12 \%$ being recorded for factories in the Northern Province. According to Kelegama and Epaarachci (2003), the reasons for high turnover and absenteeism are due to poor working environment, worker stress, and poor social image of factory workers. There is little emphasis placed on the importance of training and its role in improving 
productivity by factory owners/managers. Often, managers do not view training as an investment and are unwilling to incur expenditure on it (Kelegama and Epaarachci, 2003).

The persons who are responsible for managing human beings as well as engaging in grass root work in the apparel industry are also imperative, because they have to have a strong power to control the human beings toward organizational success or being controlled the human beings towards organizational success in short term as well as in long term. The executive and non-executive employees in an organization have been affected by many factors to determine their job performance. Among those, the job satisfaction (Locke, 1976: Mitchell \& Larson, 1987: Luthan, 1992: Robbins, 2003) may be a major root to determine the degree of executives and non-executive employees' effort in an organization. In addition to the job satisfaction, job involvement (Robbins, 1996 and Moorhead \& Griffin, 1999) and organizational commitment (Luthan, 1992: Strrees, 1997: Moorhead \& Griffin, 1999: Rao, 1999) are two important attitudinal factors to determine the job performance of the workers. Therefore job involvement and organizational commitment are two major attitudinal factors of executive and non-executive employees to keep their job performance in an organization.

It is argued that the current awful nature of human utilization in apparel industry in Sri Lanka may result in job dissatisfaction, low organizational commitment and job involvement which affect executive employees' and non-executive employees' performance as a major factor or as a minor factor. The performance of an executive or a non-executive employee may be determined by degree of his or her job satisfaction, organizational commitment and job involvement. Here, therefore, the researcher attempted to find out impact of the attitudinal factors such as job satisfaction, organizational commitment and job involvement on determining the job performance of executive and non-executive employees in the apparel industry in Sri Lanka.

The theoretical and empirical evidence elucidates the different factors for job performance of an employee such as personality (Robbins, 2003), organizational structure (Robbins, 2003), organizational culture (Moorhead and Griffin, 1999: Robbins, 2003), motivation (Moorhead and Griffin, 1999: Robbins, 2003), group (Moorhead and Griffin, 1999), and group cohesiveness (Moorhead \& Griffin, 1999: Robbins, 2003). The attitudinal factors such as job satisfaction (Locke, 1976: Mitchell \& Larson, 1987: Luthan, 1992: Robbins, 2003)), organizational commitment (Luthan, 1992: Strees, 1997: Moorhead \& Griffin, 1999: Rao, 1999), and job involvement (Moorhead \& Griffin, 1999: Robbins, 2003) are very important factors that determine the job performance of an individual in the organizational context. However, the importance of each variable to the job performance of an employee may differ. Therefore, it seems that there is a gap in the empirical knowledge available, especially in Sri Lanka with regard to the impact of job satisfaction, organizational commitment, and job involvement on the job performance of executive and non-executive employees in the Sri Lankan Apparel industry. Therefore, the problem addressed in this study is to investigate the extent to which job satisfaction, organizational commitment and job involvement affect job performance of executive and non-executive employees in apparel industry in Sri Lanka and to examine the behavior of attitudes of executives and non-executives in apparel industry. 


\section{Research Framework}

Job satisfaction: According to Brayfield and Crockett (1955), Vroom (1964), Organ (1977), Abedel-Halim (1980), Parasuraman and Futrell (1983), Argyle (1988), Argyle (1999), Rao (1999), Robbins (2003), AL-Badayneh and Sonnad [On line $\left.{ }^{4}\right]$ [31/08/2004], Lawler and Porter's (1967) (AL-Badayneh and Sonnad [On line ${ }^{4}$ [31/08/2004]), Steers (1981), Woodruff (1988), Sullivan and Bhaget (1992), Judge, Thoresen, Bono, and Patton (2001), etc stressed that there is a positive relationship between the job satisfaction and the job performance of an employee. Thus, the first hypothesis of this study was as follows:

Hypothesis 1: There is a positive relationship between job satisfaction and job performance of executive and non-executive employees in the apparel industry in Sri Lanka.

Organizational commitment: According to Kiesler and Sakumura (1966), Mowday, Porter and Steers (1982), Randall (1987), Mitchell and Larson (1987), Robbins (1996), Luthan (1992), Meyer and Allen (1994), Strees (1997), Moorhead and Griffin (1999), Rao (1999), Foong, and Loke, [On line ${ }^{8}$ [ [31/08/2004], and Orpen and Pool [On line $\left.{ }^{6}\right]$ [31/08/2004]), there is a positive relationship between the organizational commitment and the job performance of an employee. Based on the arguments and empirical evidence, the second hypothesis of this study was as follows:

Hypothesis 2: Organizational commitment of executive and non-executive employees in the apparel industry in Sri Lanka has a positive relationship with their job performance.

Job involvement: There are theoretical arguments and empirical evidence (Lodahl and Kejner (1965), Batlis (1978), Sekaran and Mowday (1981), Jewel (1985), Sekaran (1989), John, Sampo, Ian, Richard, Douglas (1989) and Robbins (1996)) linking job involvement with job performance. A positive relationship exists between the job involvement and the job performance. Hence the third hypothesis of this study was formulated as:

Hypothesis 3: Job involvement of the executive and non-executive employees in the apparel industry in Sri Lanka is positively related to their job performance.

The simultaneous effect of three independent variables including job satisfaction, organizational commitment and job involvement on job performance of executive and nonexecutive employees are also important to investigate. Therefore, the fourth hypothesis of this study was formulated as follows:

Hypothesis 4: Job satisfaction, organizational commitment and job involvement will significantly explain the variance of the job performance of the executive and nonexecutive employees in the apparel industry in Sri Lanka.

Relevant schematic diagram is shown in figure: 1. Job performance of executive and nonexecutive employees is labeled as the dependent variable. Job satisfaction, organizational commitment and job involvement of executive and non-executive employees are labeled as independent variables. 
Figure: 1 Schematic Diagram of the Research Framework

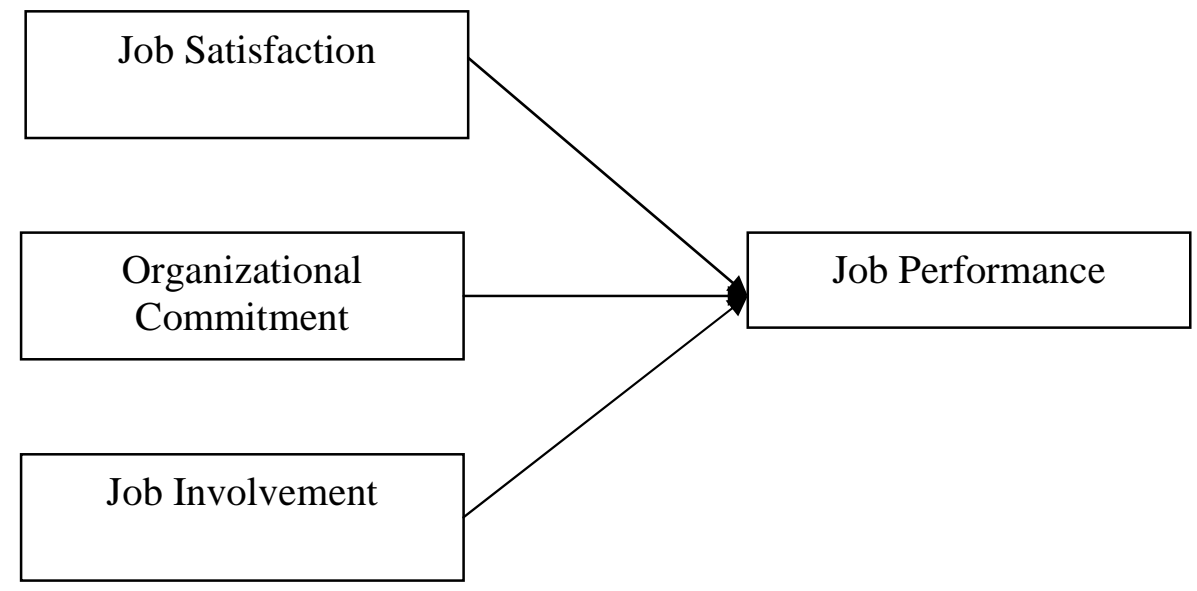

\section{Study Design}

\section{Method}

The objective of the study was to investigate three selected factors affecting job performance of the executive and non-executive employees in apparel industry in Sri Lanka. Three variables, which are considered to be important in the job performance of the executive and non-executive employees, have been identified as possible contributing factors. The objective is to establish the relationships between these independent variables and the dependent variable. Therefore, the type of investigation of this study was correlational rather than causal study. Correlation is a statistical technique for quantifying the strength of association between variables (Rosenberg and Daly, 1993). In a correlational study, the research is conducted in the natural environment of the organizations minimizing the researcher's interference in the natural flow of events (Sekaran, 1992). This study was analytical in nature, because according to Sekeran (1992), studies that engage in hypotheses testing usually explain the nature of certain relationships, or establish the difference among groups or the independence of two or more factors in a situation. In this study there were four hypotheses to be tested. They explain the nature of the relationship between the independent variables and the dependent variable. This was a field study because it examined the factors affecting job performance of the executive and non-executive employees in natural working environment of apparel industry. None of the variables were controlled or manipulated. As the study was conducted in natural environment where events normally occur, that is non - contrived setting. No any artificial or contrived setting was created for the study. According to Sekaran (1992), correlation studies are usually done in non-contrived field setting with minimal researcher interference. This study took one month for the collection of data. The data for the study were collected within a particular time period and there was no subsequent extension of the 
research contemplated. Hence, according to Zikmund, (1997), and Sekaran (1999) (as in Opatha and Ismail, 2003) the study was cross - sectional in nature. The unit of the study was individual: executive and non-executive employees in the apparel industry in Sri Lanka.

This study relied upon the survey method for the collection of the data as it was thought to be more appropriate method. According to Rosenberg and Daly (1993), survey is a technique for exploring the nature of personal characteristics and perceptions by analyzing the answers to a set of carefully developed questions. The survey method is versatile in its greatest strength being the only practical way to gather various types of information and the most economical way in many situations (Emory, 1980). Therefore, the survey method characterized by a mail and e-mail questionnaire was selected as the method of data collection in this study. This study was purely based on primary data. The non-contrived field-setting environment was used to collect these primary data. Therefore, the survey method was found to be more suitable to collect required original data because of its comparative advantages in terms of time and cost. The present study involved formulation and testing of hypotheses with a view to establish the correlations between the dependent variable and the independent variables. The study needed more reliable and original data to test hypotheses. The survey was carried out among the sample of 354 executive employees and 536 non executive employees in the apparel industry in Sri Lanka. The category of the apparel industry in Sri Lanka consists of 282 small organizations (1-100 employees), 445 medium organizations (101-500 employees) and 164 large organizations (501 and more employees). The sample method of the survey was the stratified random sampling. The following table (table: 1) shows how the sample was selected by using proportionate sampling method.

Table: 1 Stratified Random Sampling for the Study

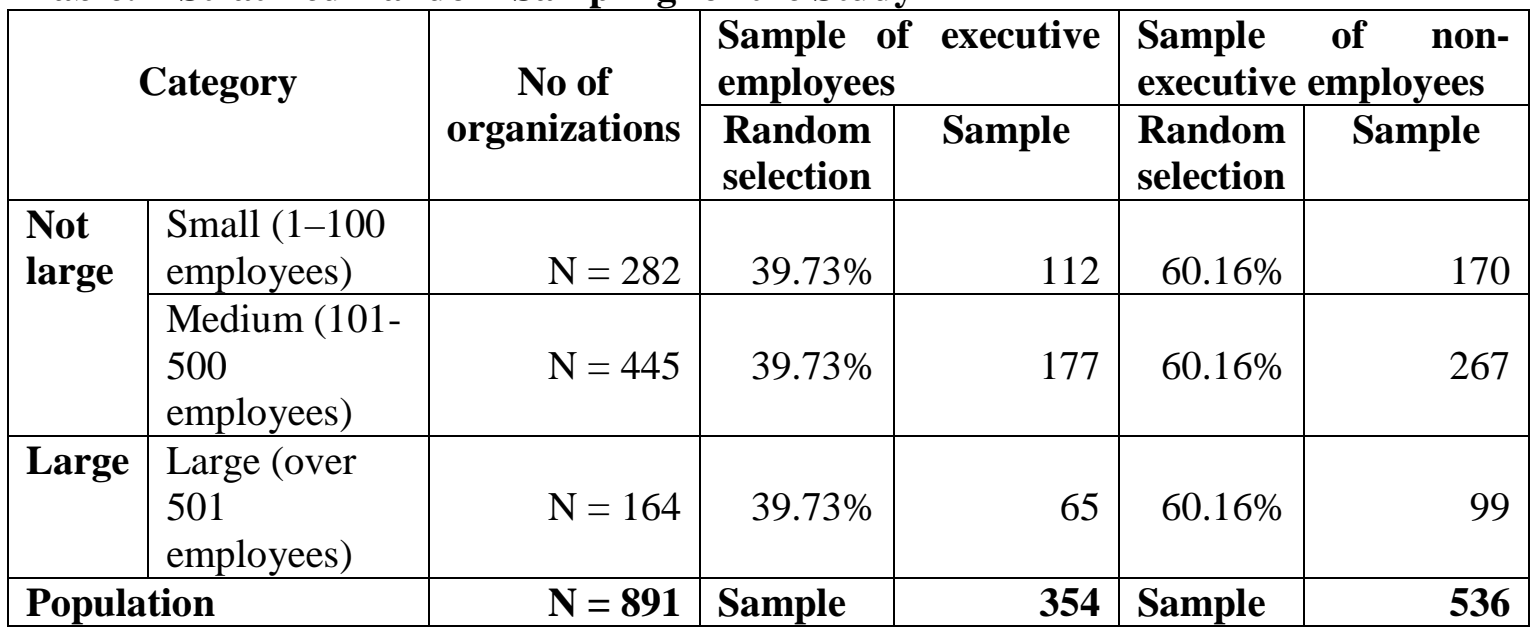

Source: Kelegama, S. and Epaarachchi, R. (2003), Garment Industry in Sri Lanka. Gopal Joshi (eds.) Garment Industry in South Asia: Rags or Riches? Competitiveness, Productivity and Job Quality in Post - MFA Environment, New Delhi: South Asia Multidisciplinary Advisory Team (SAAT), International Labour Organization 


\section{Measures}

The variable in the research model: job performance, job satisfaction, job commitment and job involvement were measured through questionnaire with five point scales, which were completed by the respondents themselves approximately as they have experienced. The variables of the study constitute interval scales.

Job performance: The dependent variable of the research model was the job performance of executive and non-executive employees in the apparel industry in Sri Lanka, which was measured by an instrument consisting of 30 statements developed by Udayakumar (2003). The job performance of executive and non-executive employees was measured in terms of three dimensions as traits, behaviors and results (Opatha, 2002). These dimensions consist of 13 aspects as given in table 2 .

Table: 2 Dimensions and Aspects of the Job Performance

\begin{tabular}{|l|l|}
\hline \multicolumn{1}{|c|}{ Dimension } & \multicolumn{1}{|c|}{ Aspects } \\
\hline \multirow{4}{*}{ Traits } & Job knowledge \\
\cline { 2 - 2 } & Cooperation \\
\cline { 2 - 2 } & Dependability \\
\cline { 2 - 2 } & Interpersonal relations \\
\cline { 2 - 2 } & Communication skills \\
\hline \multirow{4}{*}{ Behavior } & Planning work \\
\cline { 2 - 2 } & Organizing work \\
\cline { 2 - 2 } & Punctuality \\
\cline { 2 - 2 } & Attendance \\
\cline { 2 - 2 } & Speed \\
\hline \multirow{4}{*}{ Results } & Efficiency achievements \\
\cline { 2 - 2 } & Completion of work on schedule \\
\cline { 2 - 2 } & Quality of work \\
\hline
\end{tabular}

The job performance of executive and non-executive employees was measured by their responses to the questionnaire with five Point Likert scales of 'strongly agree, agree, neither agree or disagree, disagree and strongly disagree'.

Job satisfaction: The job satisfaction of executive and non-executive employees in apparel industry was also measured by the questionnaire, which was a standard questionnaire known as Minnesta Satisfaction Questionnaire (MSQ) originally developed by Wawis, Dawis, England and Lofquist in 1967 (as in Udayakumar, 2003). This questionnaire originally contained 100 question statements, with 20 different dimensions. Because of the difficulty in administrating such so lengthy questionnaire, the shortened version of the MSQ was used for this research. This shortened version contained 20 questions as statements, which hopefully gave a detailed picture of employees' specific satisfactions on the aspects given in the table 3 . 
Table: 3 Dimensions for Measuring Job Satisfaction

\begin{tabular}{|l|l|}
\hline \multicolumn{1}{|c|}{ Dimension } & \multicolumn{1}{|c|}{ Aspects } \\
\hline \multirow{5}{*}{ Work itself } & Ability to utilization \\
\cline { 2 - 2 } & Achievement \\
\cline { 2 - 2 } & Activity \\
\cline { 2 - 2 } & Authority \\
\cline { 2 - 2 } & Creativity \\
\cline { 2 - 2 } & Independence \\
\cline { 2 - 2 } Pay & Responsibility \\
\cline { 2 - 2 } Promotion opportunity & Variety \\
\hline \multirow{5}{*}{ Supervision } & Compensation \\
\hline \multirow{5}{*}{ Co-worker } & Advancement \\
\cline { 2 - 2 } & Moral value \\
\cline { 2 - 2 } & Security \\
\hline Working condition & Supervision-Human relations \\
\cline { 2 - 2 } & Supervision-technical \\
\hline & Co-workers \\
\cline { 2 - 2 } & Recognition \\
\cline { 2 - 2 } & Social services \\
\cline { 2 - 2 } & Social status \\
\hline & Company policies and practices \\
\cline { 2 - 2 } & Working conditions \\
\hline
\end{tabular}

The job satisfaction of executive and non-executive employees was measured by their responses to the questionnaire with five Point Likert scales of "very satisfied, satisfied, neither satisfied nor dissatisfied, dissatisfied and very dissatisfied'.

Organizational Commitment: The organizational commitment of executive and nonexecutive employees in the apparel industry in Sri Lanka was also measured by the use of an instrument developed by Mowday, Steer, and Porter in 1979. The organizational commitment was measured in three dimensions which included loyalty to the organization, personal identification with the organization and belief in and acceptance of the values and goals of the organization. The five point Likert scales of 'strongly agree, agree, neither disagree nor agree, disagree and strongly disagree' were used in the questionnaire to measure the organizational commitment. These dimensions and relevant aspects are given in table 4. 
Table: 4 Dimensions for Measuring Organizational Commitment

\begin{tabular}{|l|l|}
\hline \multicolumn{1}{|c|}{ Dimension } & \multicolumn{1}{c|}{ Aspects } \\
\hline \multirow{4}{*}{ Loyalty to the organization } & High level effort \\
\cline { 2 - 2 } & Acceptance of job assignment \\
\cline { 2 - 2 } & Preference to work \\
\cline { 2 - 2 } & Work to retain \\
\cline { 2 - 2 } & Caring about the fate of the organization \\
\hline \multirow{4}{*}{ Personal identification } & Express about organization \\
\cline { 2 - 2 } & Feeling of inspiration of the organization \\
\cline { 2 - 2 } $\begin{array}{l}\text { Belief in and acceptance of values and goals } \\
\text { of the organization }\end{array}$ & $\begin{array}{l}\text { Feeling of the quality of the organization } \\
\text { organizational values }\end{array}$ \\
\cline { 2 - 2 } & Feeling of choice of the organization \\
\hline
\end{tabular}

Job Involvement: The job involvement of human resource manager was also measured by an instrument, which was also a standard questionnaire developed by Lodhal and Kejner in 1965. The job involvement was measured under 5 dimensions which include caring about work, personal involvement in work, sense of duty towards work, tendencies that avoid causing to work and pride in the organization. The instrument contained 20 statements to measure the job involvement under the above five dimensions. The five point Likert scales of 'strongly agree, agree, neither disagree nor agree, disagree and strongly disagree' were used in the questionnaire to measure the job involvement.

\section{Validity and Reliability}

Validity refers to the extent to which an instrument measures what it is supposed to measure and a measuring instrument is valid when it does what is intended to do. Dunn (2001) defined the validity as the degree to which an observation or a measurement corresponds to the construct that was supposed to be observed or measured. Validity can be measured through different forms such as content validity, criterion - related validity, and construct validity (Opatha, 2003). The questionnaire provides an adequate coverage by embodying an adequate number of items that represent variables of interest ensuring the content validity of the instrument. In constructing the questionnaire, serious thought was given to identify the variables, which were mostly related to the research problem and objectives. Hypotheses were formulated based on these variables and indicators or elements were developed by operationalizing the variables. Content validity is concerned with the representativeness or sampling adequacy of the content of the measuring instrument, such as the items or questions it contains. As such content validity of the questionnaire was protected by embodying sufficient number of question items related to all the variables of interest in this study.

A measuring instrument is reliable if it consistently yields similar results at repeated administrations. Therefore, the questionnaire of this study had to be tested to see whether it yields similar results in repeated administrations. Reliability refers to a measure's stability or consistency across time (Dunn, 2001). It is how well the instrument consistently and stably measure whatever the concept it measures (Opatha, 2003). The external reliability of the instruments used to collect data was examined by test - retest method. The test was 
carried out using ten executive and ten non-executive employees from the apparel industry in Sri Lanka with two weeks time interval between two administrations. As shown in table 5 the coefficients of the Test - retest of the instruments indicate that each instrument had a good external reliability.

Table: 5 Results of Test - Retest

\begin{tabular}{|l|c|}
\hline Instruments & Test-retest coefficient \\
\hline Job performance & 0.701 \\
\hline Job satisfaction & 0.965 \\
\hline Organizational commitment & 0.821 \\
\hline Job involvement & 0.732 \\
\hline
\end{tabular}

The internal item consistency reliability was examined with Cronbach's Alpha test. The results of Cronbach's Alpha test are given in the table 6, which suggests that the internal reliability of each instrument was satisfactory.

Table: 6 Cronbach's Alpha Coefficients

\begin{tabular}{|l|c|}
\hline Instruments & Cronbach's Alpha \\
\hline Job performance & 0.852 \\
\hline Job satisfaction & 0.792 \\
\hline Organizational commitment & 0.910 \\
\hline Job involvement & 0.845 \\
\hline
\end{tabular}

The content validity of the instruments was ensured by the conceptualisation and operationalization of the variables using the available literature and indirectly by the high internal consistency reliability of the instruments as denoted by the Alphas.

\section{Techniques of Data Analysis}

Data collected from primary (questionnaire) source were analyzed using the computer based statistical data analysis package, SPSS (version 13.0) for validity, reliability, and relationship testing. The data analysis included univariate, bivariate and multivariate analyses.

\section{Results}

To investigate the responses for independent and dependent variables of the executive and non-executive employees of the apparel industry, univaraite analysis was used. The results of the univariate analysis are given in the table 7.

Table: 7 Univariate Analysis

\begin{tabular}{|l|r|r|r|r|r|r|r|r|}
\hline \multirow{2}{*}{} & \multicolumn{4}{|c|}{ Executive workers } & \multicolumn{4}{c|}{ Non-executive workers } \\
\cline { 2 - 10 } & \multicolumn{1}{|c|}{ PJP } & \multicolumn{1}{c|}{ JS } & \multicolumn{1}{c|}{ OC } & \multicolumn{1}{c|}{ JI } & \multicolumn{1}{c|}{ PJP } & \multicolumn{1}{c|}{ JS } & \multicolumn{1}{c|}{ OC } & \multicolumn{1}{c|}{ JI } \\
\hline Mean & 3.0125 & 3.1756 & 2.9345 & 2.7678 & 2.614 & 3.0789 & 2.1721 & 1.9786 \\
\hline Median & 2.876 & 3.000 & 2.756 & 2.543 & 2.431 & 2.986 & 1.973 & 1.765 \\
\hline Mode & 3.15 & 3.20 & 3.10 & 2.90 & 2.87 & 3.10 & 2.20 & 2.10 \\
\hline Std. Deviation & 0.256 & 3.317 & 0.452 & .0 .365 & 0.369 & 0.815 & 0.932 & 0.532 \\
\hline Variance & 0.214 & 0.112 & 0.172 & 0.358 & 0.045 & 0.075 & 0.125 & 0235 \\
\hline
\end{tabular}




\begin{tabular}{|l|r|r|r|r|r|r|r|r|}
\hline Skewness & -0.569 & -0.525 & 1.865 & 0.321 & -0.368 & -0.432 & 0.378 & 0.124 \\
\hline Std. error of Skewness & 0.135 & 0.124 & 0.123 & 0.124 & 0.125 & 0.142 & 0.135 & 0.124 \\
\hline Kurtosis & 0.224 & 0.228 & 4.832 & 0.422 & -0.365 & -0.156 & 0.242 & 0.256 \\
\hline Std. error of Kurtosis & 0.54 & 0.48 & 0.247 & 0.247 & 0.587 & 0.342 & 0.246 & 0.245 \\
\hline Range & 1.69 & 1.96 & 3.60 & 1.78 & 1.98 & 2.40 & 2.73 & 2.98 \\
\hline
\end{tabular}

Note: PJP $=$ Perceived Job Performance, JS $=$ Job Satisfaction, OC $=$ Organizational Commitment, JI = Job Involvement

According to table 7 , level of perceived job performance, job satisfaction, organizational commitment and job involvement of executive employees as well as non executive employees in apparel industry are normally distributed. As per means, job satisfaction of both employees is at moderate level. Organizational commitment and job involvement of the both employees are less than the moderate level. Perceived job performance of executive employees is quite moderate while that of non-executive employees is almost average.

The bivariate analysis, Pearson's Correlation between job satisfaction, organizational commitment, and job involvement with job performance of the executive and nonexecutive employees in the apparel industry are illustrated in table no 8.

Table: 8 The Pearson's Correlation between Independent Variable and Dependent Variable

\begin{tabular}{|l|c|c|c|c|c|c|}
\hline \multirow{2}{*}{} & \multicolumn{3}{|c|}{ Executive workers } & \multicolumn{3}{c|}{ Non-Executive workers } \\
\cline { 2 - 7 } & JS & OC & JI & JS & OC & JI \\
\hline Correlation & 0.898 & 0.692 & 0.721 & 0.815 & 0.356 & 0.398 \\
\hline Sig. (1-tailed) & .000 & .000 & .000 & .000 & .000 & .000 \\
\hline
\end{tabular}

Correlation is significant at the 0.01 level (1-tailed)

According to the Pearson's correlation coefficients of job satisfaction, organizational commitment, job involvement in relation to job performance of executive employees and non-executive employees, all independent variables are positively and significantly correlated with job performance regarding both employees. However, job satisfaction is the independent variable with the highest correlation coefficient regarding both employees when compared with the other variables. Linkage of organizational commitment and job involvement with job performance of non - executive employees in the apparel industry in Sri Lanka is positive significantly.

The results of simple regression analysis of the three independent variables (job satisfaction, organizational commitment and job involvement) against the dependent variable (job performance) are given in table 9. 
Table: 9 Results of Simple Regression Analysis

\begin{tabular}{|l|r|r|r|r|r|r|}
\hline \multirow{2}{*}{ Variable } & \multicolumn{2}{l|}{ Job satisfaction } & \multicolumn{2}{l|}{$\begin{array}{l}\text { Organizational } \\
\text { commitment }\end{array}$} & \multicolumn{2}{l|}{ Job involvement } \\
\cline { 2 - 7 } & Executive & $\begin{array}{l}\text { Non- } \\
\text { executive }\end{array}$ & Executive & $\begin{array}{l}\text { Non- } \\
\text { executive }\end{array}$ & Executive & $\begin{array}{l}\text { Non- } \\
\text { executive }\end{array}$ \\
\hline Method & Linear & Linear & Linear & Linear & Linear & \multicolumn{1}{c|}{ Linear } \\
\hline R Square & 0.8064 & 0.4789 & 0.5198 & 0.6642 & 0.1267 & 0.1584 \\
\hline $\begin{array}{l}\text { Adjusted R } \\
\text { Square }\end{array}$ & 0.789 & 0.681 & 0.125 & 0.321 & 0.236 & 0.352 \\
\hline F & 1606.2 & 210.3 & 18.304 & 236.0 & 69.223 & 241.2 \\
\hline Significance & $<0.000$ & $<0.000$ & $<0.000$ & $<0.000$ & $<0.000$ & $<0.000$ \\
\hline B-constant & 1.023 & 0.936 & 1.321 & 0.365 & 2.201 & 0.681 \\
\hline b-Value & 0.574 & 0.712 & 0.423 & 0.125 & 0.325 & 0.132 \\
\hline
\end{tabular}

According to the table 9, all the independent variables are positively related with the dependent variable in respect of the both employee categories.

The multicollinearity test was carried out to find out any significantly strong correlation between the independent variables (see table 10).

Table: 10 Results of Multicollinearity Diagnostic Test

\begin{tabular}{|l|c|c|c|c|c|c|}
\hline \multirow{2}{*}{} & \multicolumn{3}{|c|}{ Executive workers } & \multicolumn{3}{c|}{ Non-Executive workers } \\
\cline { 2 - 7 } & JS & OC & JI & JS & OC & JI \\
\hline JS & - & 0.125 & 0.236 & - & 0.201 & 0.196 \\
\hline OC & 0.134 & - & 0.125 & 0.241 & - & 0.156 \\
\hline JI & 0.236 & 0.214 & - & 0.124 & 0.132 & - \\
\hline
\end{tabular}

Correlation is significant at the 0.01 level (1-tailed)

According to Multicollinearity diagnostic test, all independent variables are weakly correlated with each other. Hence, as there are no correlation coefficients as strong as 0.9 and above among the independent variables, it is statistically evident that no multicollinearity exists among the independent variables. Multicollinearity is a statistical problem sometimes present in multiple - regression analysis in which the reliability of the regression coefficients is reduced, owing to a high level of correlation between the independent variables (Levin and Rubin, 2000). The results of multiple regression of the three independent variables (job satisfaction, organizational commitment and job involvement) against the dependent variable (job satisfaction) are shown in the table 11.

Table: 11 Results of Multiple Regression Analysis

\begin{tabular}{|l|r|r|r|r|r|r|}
\hline $\begin{array}{l}\text { Employee } \\
\text { category }\end{array}$ & $\begin{array}{l}\text { Multiple } \\
\text { R }\end{array}$ & $\begin{array}{l}\text { R } \\
\text { Square }\end{array}$ & $\begin{array}{l}\text { Adjusted } \\
\text { R Square }\end{array}$ & $\begin{array}{l}\text { Standard } \\
\text { error of } \\
\text { the } \\
\text { Estimate }\end{array}$ & F & Sig. F \\
\hline Executive & 0.952 & .841 & 0.831 & 0.1208 & 511.762 & 0.000 \\
\hline Non-Executive & 0.918 & .833 & 0.825 & 0.1621 & 412.632 & 0.000 \\
\hline
\end{tabular}


The R Square is 0.841 , which indicates that $84 \%$ of the variation in job performance of executive employees in the apparel industry is explained by the three independent variables jointly. The $\mathrm{F}$ value is 511.762 , which is significantly at $1 \%(\mathrm{p}=0.000)$, which suggests that the three independent variables have significantly explained $84 \%$ of the variation in the job performance. The R Square is 0.833 , which indicates that $83 \%$ of the variation in job performance of non-executive employees in the apparel industry is explained by the three independent variables jointly. The $\mathrm{F}$ value is 412.632 , which is significant at $1 \%$ (p $=0.000$ ) suggesting that $83 \%$ of the variation in the job performance is statistically significant.

The strength of the influence that each of the independent variables had on the dependent variable (job performance) was determined by the use of multi regression coefficients of the independent variables. The influence of each independent variable is shown in the table 12.

Table: 12 Influence of the Independent Variables on Job Performance

\begin{tabular}{|l|c|c|c|c|c|c|c|c|}
\hline \multirow{2}{*}{$\begin{array}{c}\text { Independent } \\
\text { variable }\end{array}$} & \multicolumn{4}{|c|}{$\begin{array}{c}\text { Standard } \\
\text { Beta }\end{array}$} & $\begin{array}{c}\text { Standard } \\
\text { error of } \\
\text { Beta }\end{array}$ & & Sig. t & \multicolumn{3}{c|}{$\begin{array}{c}\text { Standard } \\
\text { Beta }\end{array}$} & $\begin{array}{c}\text { Standard } \\
\text { error of } \\
\text { Beta }\end{array}$ & t & Sig. t \\
\hline $\begin{array}{l}\text { Job } \\
\text { satisfaction }\end{array}$ & 0.83 & 0.021 & 39.200 & 0.000 & 0.89 & 0.31 & 25.00 & 0.000 \\
\hline $\begin{array}{l}\text { Organizational } \\
\text { commitment }\end{array}$ & 0.12 & 0.011 & 1.936 & 0.000 & 0.10 & 0.021 & 2.360 & 0.000 \\
\hline $\begin{array}{l}\text { Job } \\
\text { involvement }\end{array}$ & 0.05 & 0.020 & 5.360 & 0.063 & 0.01 & 0.014 & 2.547 & 0.002 \\
\hline
\end{tabular}

As shown in the table 10, except job involvement of executive employees other variables have strong and significant effects on the job performance of both employee categories ( $p$ $<0.05)$.

\section{Discussion and Conclusion}

According to the results of Pearson's Product Moment correlation analysis, it was found that job satisfaction, organizational commitment and job involvement were positively and significantly correlated with perceived job performance of executives and non-executive employees as well. Hence there are statistical evidences to support to accept all the three hypotheses formulated for the study. The first hypothesis was: there is a positive relationship between job satisfaction and job performance of executive and non-executive employees in the apparel industry in Sri Lanka. It was confirmed that Job satisfaction of executive and non-executive employees in the apparel industry in Sri Lanka has a positive and significant relationship with their job performance. The second hypothesis was: there is a positive relationship between organizational commitment and job performance of executive and non-executive employees in the apparel industry in Sri Lanka. The statistical testing supported to accept that organizational commitment of executive and non-executive employees in the apparel industry in Sri Lanka has a positive relationship with their job 
performance. The third hypothesis was: job involvement of the executive and nonexecutive employees in the apparel industry in Sri Lanka is positively related to their job performance. It was substantiated that there is a positive relationship between job involvement and job performance of executive and non-executive employees in the apparel industry in Sri Lanka.

The fourth hypothesis was: job satisfaction, organizational commitment and job involvement will significantly explain the variance of the job performance of the executive and non-executive employees in the apparel industry in Sri Lanka. This hypothesis was tested using the results of multiple regression analysis. According to the results of the analysis, the $\mathrm{R}$ Square $\left(\mathrm{R}^{2}\right)$ is 0.841 , which is significant at $1 \%$ (Sig. $\mathrm{F}=0.000$ ), suggesting that the three independent variables have significantly explained $84 \%$ of the variables in the job performance of executive employees in this industry. According to the results of the multiple regression analysis on the variables with regard to non-executive employees, the $\mathrm{R}$ Square $\left(\mathrm{R}^{2}\right)$ is 0.833 , which is significant at $1 \%(\mathrm{Sig} . \mathrm{F}=0.000)$. It suggests that the three independent variables have significantly explained $83 \%$ of the variables in the job performance of non-executive employees. Therefore, according to the results of the test, hypothesis is accepted since $\mathrm{R}^{2}>0$. Hence, the data support the hypothesis that job satisfaction, organizational commitment and job involvement of the executive and nonexecutive employees in the apparel industry in Sri Lanka together will significantly explain the variance in their job performance.

The findings of this research study shall be important on the theoretical as well as practical scenario. As this research model was substantiated, the findings of study are important to improve job performance of executive and non-executive employees to this industry. As a major way of enhancing the job performance of executive and non-executive employees in the apparel industry, the programs relating to the enhancement of the job satisfaction of the executives and non-executives are to be implemented successfully. Pay (Price and Mueller, 1986: Moorhead and Griffin, 1999), promotion (opportunities) (Price and Mueller, 1986: Moorhead and Griffin, 1999), work itself (Price and Mueller, 1986: Moorhead and Griffin, 1999), mentally challenging work (Locke, 1976), equitable rewards (Locke, 1976), supportive working conditions (Locke, 1976), policies and procedures (Moorhead and Griffin, 1999) coworkers (Locke, 1976: Price and Mueller, 1986: Moorhead and Griffin, 1999), and supervisors (Price and Mueller, 1986: Moorhead and Griffin, 1999) needs (Moorhead and Griffin, 1999), aspirations (Moorhead and Griffin, 1999), and institutional benefits (Moorhead and Griffin, 1999) are the few ways of upgrading the job satisfaction of an employee. The top management of the organizations in the apparel industry should consider these factors and enhance the job satisfaction of the both employees to gain maximum contribution to achieve the organizational objectives.

The researcher believes in that the important independent variables that may account for the unexplained variable in the job performance of executives and non-executives may be the other variables, such as mental and physical ability, person energy level, personality dimensions (dependability, self - confidence), (Gordon, 1993), group, norms, organizational culture, (Hellriegel, Slocum, and Woodman, 1992) and so on. Further 
research studies are suggested to carry out to find out the effects of these factors on job performance of executive and non-executive employees in apparel industry in Sri Lanka.

\section{References}

Abedel-Halim, A. A. (1980), Effects of higher order need strength on the job performancejob satisfaction relationship, Personnel Psychology, Vol. 33, pp. 335 - 347.

AL-Badayneh, M. D. and Sonnad, S. R., An Analysis of the Self-rated Job performance and job satisfaction Relationship in Jordanian hospitals. [On line $\left.{ }^{4}\right][31 / 08 / 2004]$ <http://64.233.179.104/search?q=cache:E5lw7S8bWR0J:www.mutah.edu.jo/user homepages/nurses.pdf $+\% 22$ job+performance+and + job+satisfaction $\% 22 \&$ hl=en $\&$ ie $=$ UTF-88>

Armstrong, M. (1996), Personnel Management Practice, $6^{\text {th }}$ ed, London: Kogan Page Limited.

Boselie, P. and Paauwe, J. Human Resource Function Competencies in European Companies, [On line ${ }^{1}$ ] [31/08/2004]< http://64.233.179.104/search?q=cache:Pe7eosXzKUYJ:https://ep.eur.nl/retrieve/3 301/ERS\%2B2004\%2B069\%2BORG.pdf+\%22human+resource+competency\%2 2\&hl=en\&lr=lang_en\&ie=UTF-8

Bratton, J. and Gold, J. (1994), Human Resource Management: Theory and Practice, Houndmills: The Macmillan press ltd.

Brayfield, A. H., and Crockett, W. H. (1955), Employee attitudes and employee performance. Psychological Bulletin, 52, pp.396-424.

Brockbank, W. and Ulrich, D. (2002), The new HR agenda: 2002 HRCS executive summary, University of Michigan Business School.

Chanda, J. S. (1994), Organizational Behavior, $2^{\text {nd }}$ ed, New Delhi: Vikas publishing Ltd.

Dunn, D. S. (2001), Statistics and data analysis for the behavioral sciences, New York: McGraw Hill Higher education.

Emory, C.W. (1985), Business Research Methods, $3^{\text {rd }}$ ed, Homewood, IL: Richard D. Trwin.

Fernie, S., Metcalf, D., and Woodland, S. (1994), What has human resource management achieved in the workplace? Landon: Employment policy institute.

Foong, J. and Loke, C., Leadership Behaviors: Effects on Job Satisfaction, Productivity $\begin{array}{llll}\left.\text { and Organizational Commitment. [On line }{ }^{8}\right] & \text { [31/08/2004] }\end{array}$ http://66.102.11.104/search?q=cache:pkifR3q_PlQJ:media.wiley.com/assets/49/8 8/bus_lc_jb_foong.pdf+\%22job+satisfaction+and+organizational+commitment $\%$ 22\&hl=en\&lr=lang_en\&ie=UTF-8

Greer, C.R. and Castro, M.A.D. (1986), The relationship between perceived unit effectiveness and occupational stress: The case of purchasing agents, Journal of applied behaviour science, Vol. 22, pp. 159 - 175.

Guest, D.E. (1997), Human resource management and performance: a review and research agenda, The international journal of human resource management, Vol. 08, No. 03, pp. $263-276$.

Guest, D.E., and Hoque, K. (1995), An assessment and further analysis of the 1990 workshop industrial relations survey, In D.E. Guest, S.Tyson, N. Dohery, 
K.Hoque and K. Viney (eds.) The contribution of personnel management to organizational performance, Landon: Institute of personnel and development.

Hellriegal, D., Slocum, jr, John W., and Woodman, R. W. (1992), Organizational Behavior, Edition seven, St. Paul: West Publishing Company.

Iaffaldano, M. T. and Muchinsky, P. M. (1985), Job satisfaction and job performance: A meta-analysis, Psychological Bulletin, 97, pp.251-273.

Jacobs, R. and Solomon, T. (1977), Strategies for enhancing the prediction of job performance from job satisfaction, Journal of Applied Psychology, 62, pp.417421.

Jewel, L.N. (1985), Contemporary Industrial/Organizational Psychology, Weat: St. Paul MN.

Job Satisfaction and Organizational Commitment

A Sloan Work and Family Encyclopaedia Entry. [On line $\left.{ }^{7}\right]$ [31/08/2004] http://www.bc.edu/bc_org/avp/wfnetwork/rft/wfpedia/wfpJSOCent.html

Judge, T. A., Thoresen, C. J., Bono, J. E., and Patton, G. K. (2001), The job satisfactionjob performance relationship: A qualitative and quantitative review, Psychological Bulletin, 127, pp.376-407.

Kanfer, R. (1994), Work motivation: new directions in theory and research, C.L. Coorper and I.T. Robertson (eds.) Key review in managerial psychology, New York: Wiley, pp. $158-188$.

Kelegama, S. and Epaarachchi, R. (2003), Garment industry in Sri Lanka, Gopal Joshi (eds.) Garment industry in south Asia: Rags or riches? Competitiveness, productivity and job quality in post - MFA environment, New Delhi: South Asia multidisciplinary advisory team 9SAAT), International Labor organization.

Kiesler and Sakumur, (1966), Understanding Human Behavior, Personnel/ Human Resource Management, New York: Konark publisher pvt ltd.

Landy, F.J. (1989), Psychology of Work Behavior, Edition, fourth, Pacific Grove Calif: Brooks/Cole.

Lawler, E. E., III and Porter, L. W. (1967), The effects of performance on job satisfaction, Industrial Relations, 7, pp.20-28.

Locke, E.A. (1976), The nature and causes of job satisfaction, In M. D. Dunnette, Handbook of industrial and organizational psychology, Chicago: McNally.

Locke, E.A. and Latham, G.P. (1990), A theory of goal setting and task performance, Englewood: Prentice - Hall.

Lodahl, T.M., and Kejner, M. (1965), The definition and measurement of job involvement, Journal of applied psychology, Vol. 49, No. 01, pp. $24-33$.

Meyer, J. P., and Allen, N. J. (1997), Commitment in the workplace: Theory, research, and application, Thousand Oaks, CA: Sage.

Meyer, J. P., Stanley, D. J., Herscovitch, L., and Topolnyutsky, L. (2002), Affective, continuance, and normative commitment to the organization: A meta-analysis of antecedents, correlates, and consequences, Journal of Vocational Behaviour, 61, pp.20-52.

Moorhead, G. and Griffin, R.W. (1999), Organizational Behaviour; Managing people and organizations, $3^{\text {rd }}$ ed, Mumbai: Jaico Publishing House. 
Morrison, K. A. (1997), How franchise job satisfaction and personality affects performance, organizational commitment franchiser relations, and intention to remain, Journal of Small Business Management, 35, pp.39-68.

Motowidlo, S.J., Packard, J.S and Manning, M.R. (1986), Occupational stress: Its causes and consequences for job performance, Journal of applied research, Vol. 71, pp. 618-629.

Mowday, R., Porter, L., and Steers, R. (1982), Employee - organization linkage: the psychology of commitment, absenteeism, and turnover, In P.Worr (ed), Organizational and occupational psychology, pp. 219 - 229, London: Academic press.

Opatha, H.H.H.D.N.P. (2002), Performance Evaluation of Human Resources, Colombo: Institute of Management Sciences.

Opatha, H.H.HD.N.P. and Ismail, Z. B. (2002), An empirical investigation of management-related contributing to labor-management relationship in manufacturing firms in Sri Lanka, NMMS journal, January-June, pp. 74-85.

Opatha, H.H.H.D.N.P. (2003), Research methods for human resource management: questions and answers, Part 1. Colombo: Author Publication.

Organ, D. W. (1988), A restatement of the satisfaction-performance hypothesis, Journal of Management, 14, pp.547-557.

Organ, D.W. (1977), A reappraisal and reinterpretation of satisfaction causes performance hypothesis. Academy of Management Review, vol. 2, pp. 46-53.

Petty, M.M., Mcgee, G. W., Gail, D. E., and Cavender, J. W. (1984), A meta-analysis of the relationships between individual job satisfaction and individual performance, Academy of Management Review, 9, (4), pp.712-721.

Price, J.L. and Mueller, C.W. (1986), Handbook of Organizational Measurement, Marshfield, MA: Pitman Publishing.

Randall, D.M. (1987), Commitment and the organization: the organization man revisited, Academic of Management Review, July pp. 460 - 471.

Rao, T.V. (2000), HRD Audit, evaluating the human resource function for business improvement, New Delhi: Response book.

Robbins, S. P. (1996), Organizational behaviour: concepts, controversies, and applications, $5^{\text {th }}$ ed, London: Prentice - Hall international, inc.

Robbins, S. P. (2003), Organizational behavior, $10^{\text {th }}$ ed, New Delhi: Prentice - Hall pf India Private Limited.

Rosenberg, M. K. and Daly, B. H. (1993), Foundation of behavioral research, United State of America: Harcourt Grace College Publishers.

Schwab, D. P, and Cummings, L. L. (1970), Theories of performance and satisfaction: A review, Industrial Relations, 9, pp.408-430.

Sekaran, U. (1992), Research method for business: A skill building approach. Ed $3^{\text {rd }}$, New York: Hohn Wiley \& Sons, Inc.

Sekaran, U. and Moday, R.T. (1981), Across - cultural analysis of the influence of individual and job characteristics of job involvement. International Review of Applied Psychology, New Delhi.

Schwab, D. P. and Cumming, L. L. (1970), Theories of performance and satisfaction: a review, Industrial Relations, 9, pp.408 - 430. 
Skibba, J. S. Personality and job satisfaction: an investigation of central Wisconsin firefighters [On line $\left.{ }^{5}\right]$ [31/08/2004]

Steers, R. M. (1975), Effects of need for achievement on the job performance-job attitude relationship, Journal of Applied Psychology, vol. 60, pp. 678-682.

Steers, R. M. (1981), Introduction to Organizational Behavior, Glenview, IL: Scott Foresman.

Steers, R.M. (1977), Antecedents and outcomes of organizational commitment, Administrative sciences quarterly, pp. 46 - 56.

Story, J. (1989). New perceptive on human resource management, Landon: Routledge.

Sullivan, S.E. and Bhaget, R.S. (1992), Organizational stress, job satisfaction, and job performance: where do we go from here? Journal of Management, Vol. 18, pp. $353-374$.

Udayakumar, R. (2003), An empirical study on the job attitudinal factors influencing the job performance of non - academic employees in the universities in the Eastern province of Sri Lanka, Dissertation submitted to the University of Sri Jayewardenepura, Unpublished.

Umstot, D. D. (1984), Understanding organizational behavior: concepts and applications, St. Paul: West Publishing Co.

Vroom, V. H. (1964). Work and motivation, New York: Wiley. 